\title{
Morphometric Analysis of the Effectiveness of Different Concentrations of Sodium Hypochlorite Associated with Rotary Instrumentation for Root Canal Cleaning
}

\author{
Flares BARATTO-FILHO ${ }^{1}$ \\ Jacy Ribeiro de CARVALHO Jr. ${ }^{1}$ \\ Luiz Fernando FARINIUK ${ }^{1}$ \\ Manoel D. SOUSA-NETO ${ }^{1}$ \\ Jesus Djalma PÉCORA ${ }^{2}$ \\ Antônio Miranda da CRUZ-FILHO ${ }^{1}$ \\ ${ }^{1}$ Department of Endodontics, Faculty of Dentistry, University of Ribeirão Preto, Ribeirão Preto, SP, Brazil \\ ${ }^{2}$ Department of Restorative Dentistry, Faculty of Dentistry, University of São Paulo, Ribeirão Preto, SP, Brazil
}

\begin{abstract}
This study evaluated the cleaning capacity of Profile .04 instruments with different concentrations of $\mathrm{NaOCl}$ solutions on flattened root canals. Twenty central mandibular incisors were divided into 4 groups: Group I: 0.5\% NaOCl; Group II: $1 \% \mathrm{NaOCl}$; Group III: $5 \%$ $\mathrm{NaOCl}$; Group IV: distilled and deionized water. After chemomechanical preparation, the teeth were submitted to histological preparation and morphometric analysis. Morphometric analysis showed that the $5 \% \mathrm{NaOCl}$ was significantly more efficient in cleaning the root canal than $0.5 \% \mathrm{NaOCl}$ and distilled water, which had the lowest levels of cleaning of the root canals $(\mathrm{p}<0.01)$.
\end{abstract}

Key Words: cleaning, sodium hypochlorite, rotary instrumentation, root canal.

\section{INTRODUCTION}

One of the greatest concerns of the endodontist is the cleaning, shaping and disinfection of the root canal. According to Schilder (1), this leads to a tapered conic form from the crown to the apex, simulating the original root canal and permitting complete filling of the root canal system.

The internal anatomy of human teeth is complex and variable. A tooth does not present just a simple root canal but a complex system of root canals composed of lateral, collateral, re-current, secondary, accessory, reticular, intra-canaliculli canals and multiple foraminal openings.

The action of the endodontic instrument during chemomechanical preparation occurs only in the root canal and does not directly reach the entire radicular complex. Therefore, the cleaning of root canals is a challenge. This cleaning occurs during the chemomechanical preparation eliminating irritants such as bacteria and their sub-products, degenerated pulp and contaminated dentine. This process occurs by the mechanical action of the instruments against the principal canal wall combined with the chemical action of the irrigating solutions and the physical process of irrigationaspiration.

The development of nickel-titanium (Ni-Ti) files was a major advance, especially due to their flexibility, which allows the use as a manual instrument or with automized techniques. Currently, many types of Ni-Ti files exist with new characteristics, new designs, changes in standard taper and different file lengths. Rotary Ni$\mathrm{Ti}$ instruments have shown to efficiently create a conic tapered root canal with low risk of forming steps or 
transporting the root canal. They also require less time than the manual technique (2). However, the cleaning of the endodontic system is not always effective $(3,4)$, especially in flattened root canals or when the canal does not allow the action of the instruments. Therefore, chemical solutions are of fundamental importance during chemomechanical preparation.

Among the chemical solutions currently used, different concentrations of sodium hypochlorite $(\mathrm{NaOCl})$ are the most common and are accepted worldwide due to properties that contribute to effective chemomechanical debridement of a root canal system. $\mathrm{NaOCl}$ acts as a lubricant for instrumentation and can flush loose debris from root canals (5). $\mathrm{NaOCl}$ promotes clearing, dissolves both vital and nonvital tissue and has antibacterial action (6).

Therefore, using an optic microscope, this study evaluated the cleaning capacity of the Profile .04 system associated to different concentrations of $\mathrm{NaOCl}$.

\section{MATERIAL AND METHODS}

Twenty human mandibular central incisors, extracted due to periodontal disease, with a mesiodistalflattened root and a radiographically confirmed single root canal were used in this study. The teeth presented completely formed roots and apical foramen with standard diameter of a \#15 file. The teeth were stored in $0.1 \%$ thymol solution and maintained at $4{ }^{\circ} \mathrm{C}$ before use.

Conventional access was made, and a \#10 K-file

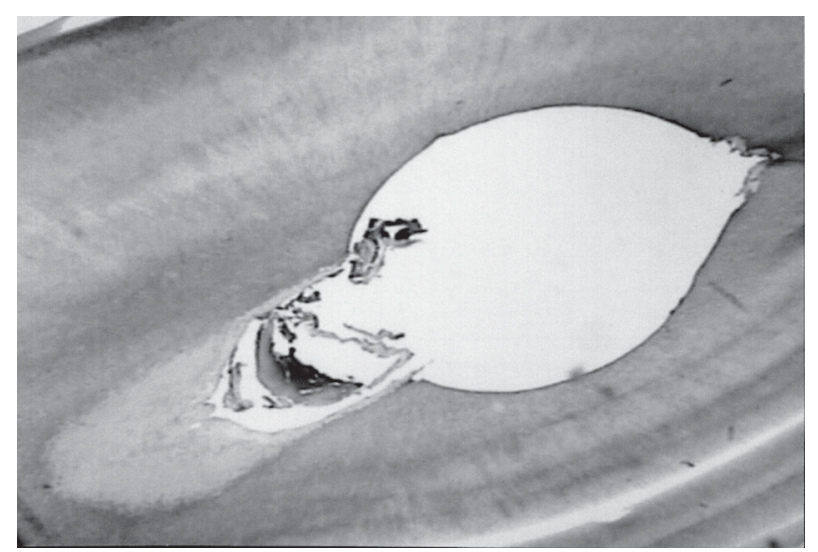

Figure 1. Apical third with a round preparation after instrumentation with ProFile taper .04 nickel-titanium files and irrigation with distilled and deionized water showing areas where the instrument did not touch (hematoxylin and eosin; original magnification, 40X).
(Dentsply-Maillefer, Ballaigues, Switzerland) was introduced into each canal until it appeared at the apical foramen. The working length was established by subtraction of $1.0 \mathrm{~mm}$ from this measurement. The teeth were randomly divided into four groups of 5 teeth each. All teeth were prepared by the crown-down technique, using rotary instrumentation (TC 3000 electric motor, Nouvag, Goldach, Switzerland) with ProFile .04 Ni-Ti files (Dentsply-Maillefer, Ballaigues, Switzerland), varying the concentration of sodium hypochlorite: Group I: $0.5 \%$ sodium hypochlorite; Group II: $1 \%$ sodium hypochlorite; Group III: 5\% sodium hypochlorite; Group IV: distilled and deionized. After initial enlargement with a stainless steel \#15 file, an ascending-sequential ProFile instrumentation (\#15 to \#35) was performed to the working length. Two teeth were used as negative controls, in which no procedure was carried out. Irrigation with $2 \mathrm{ml}$ of the corresponding irrigating solution was performed after each file. The solution remained in the canal for $30 \mathrm{~s}$ during the instrumentation with each file. For all groups, $10 \mathrm{ml}$ of the same solution was used for final irrigation.

The apical third of each root was sectioned and removed for histological processing. The samples were immersed in $10 \%$ buffered formalin and stored for $12 \mathrm{~h}$ in the same solution until histological processing. Teeth were then washed, decalcified in $10 \%$ glycoacetic acid and embedded in paraffin. Serial transverse cross-sections $(5 \mu \mathrm{m})$ were stained with hematoxylin and eosin. Five cross-sections were randomly obtained from each apical third (25 cross-sections for each group). The

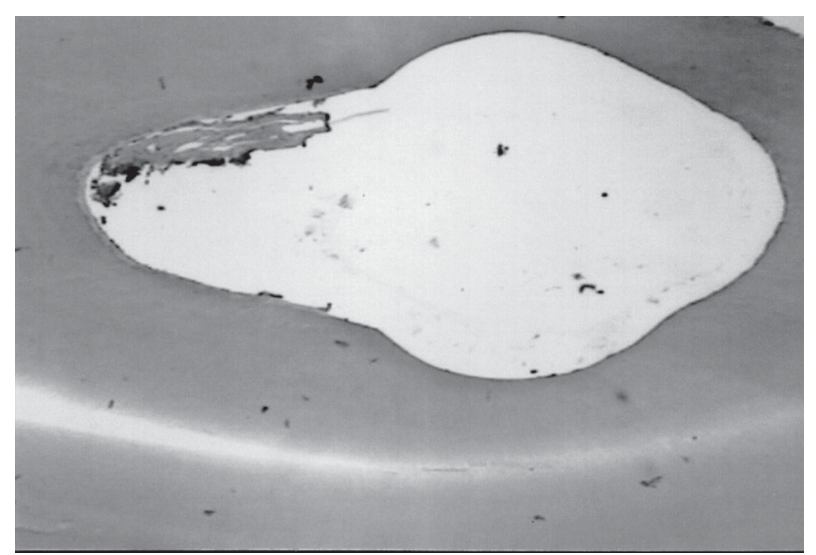

Figure 2. Apical third with a round preparation after instrumentation with ProFile taper .04 nickel-titanium files and $0.5 \%$ sodium hypochlorite irrigation showing areas where the instrument did not touch (hematoxylin and eosin; original magnification, 40X). 
cross-sections were examined with an optic microscope (40X) that was coupled to a computer where the images were recorded. A grid was placed over these images to evaluate the total canal area and the area with debris. The percentage of debris in the root canal after chemomechanical preparation was calculated and the parametric Tukey test was used for statistical analysis.

\section{RESULTS}

Morphometric analysis showed $22.57 \pm 1.24$ percent debris in canals irrigated with distilled water (Figure 1), $9.52 \pm 0.88$ percent debris in root canal irrigated with $0.5 \% \mathrm{NaOCl}$ (Figure 2), $8.90 \pm 0.93$ percent debris in canals irrigated with $1 \% \mathrm{NaOCl}$ (Figure 3), and $8.44 \pm 0.79$ percent in canals irrigated with $5 \% \mathrm{NaOCl}$ (Figure 4). Statistical analysis showed that $5 \% \mathrm{NaOCl}$ was significantly more efficient in cleaning the root canal than $0.5 \% \mathrm{NaOCl}$ and distilled water $(\mathrm{p}<0.01)$. The $1 \% \mathrm{NaOCl}$ showed an intermediate value of debris removal, and there were no significant differences ( $p>0.01)$ compared to the other two groups.

\section{DISCUSSION}

Root canal cleaning occurs during chemomechanical preparation, which eliminates bacteria, their sub-products, degenerated pulp and contaminated dentine, resulting in a surgical space for adequate sealing. This process occurs by the mechanical action of the instruments in the root canal associated to the chemical

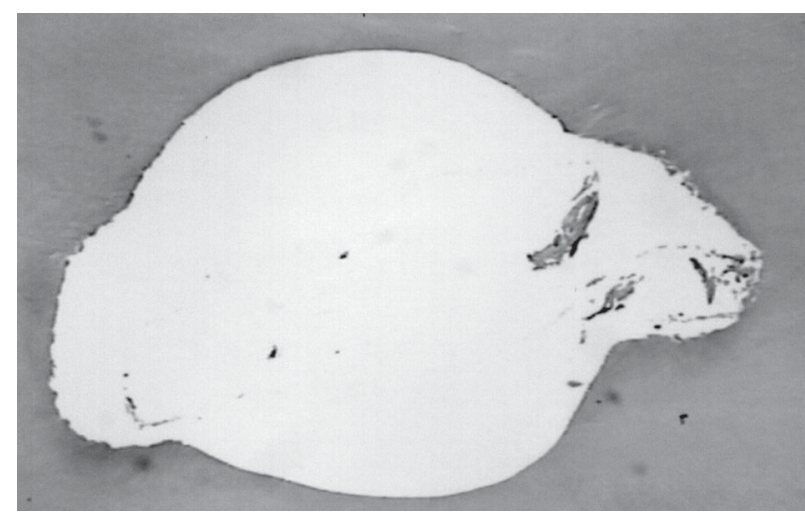

Figure 3. Apical third with a round preparation after instrumentation with ProFile taper .04 nickel-titanium files and $1.0 \%$ sodium hypochlorite irrigation showing areas where the instrument did not touch (hematoxylin and eosin; original magnification, 40X). action of the irrigating solutions and the irrigationaspiration process.

Even with the development of instruments, techniques and equipment used in Endodontics, research has shown that none of the existing techniques leads to total cleaning of the root canal system $(4,7)$.

Research shows $(3,4)$ that the apical third of the root canal is the most difficult area to clean due to the complex anatomy of this region (deltas, lateral canals). Therefore, this study evaluated only this area for percentage of debris.

Barbizam et al. (4) reported that rotary instrumentation with Profile $.04 \mathrm{Ni}$-Ti files have a delimitated area of action leaving polar areas in flattened root canals un-instrumented where the dentine canaliculi favor microorganism maintenance. This was also observed in the present study in which Profile .04 instrumentation did not act on all areas of the flattened root canal walls. Fariniuk et al. (8) reported that even in circular canals the cleaning efficiency does not depend exclusively on instrumentation. Thus, it is necessary to use an effective irrigating solution with specific properties, such as organic debris removal, or an association of instrumentation techniques to fill the void left by rotary instrumentation.

This study evaluated histologically the amount of debris in the canal after chemomechanical preparation with rotary instrumentation with ProFile .04 Ni-Ti files and different concentrations of $\mathrm{NaOCl}(0.5,1$, and $5 \%$ ). Debris is considered to be organic and inorganic remnants in the root canal system after chemomechan-

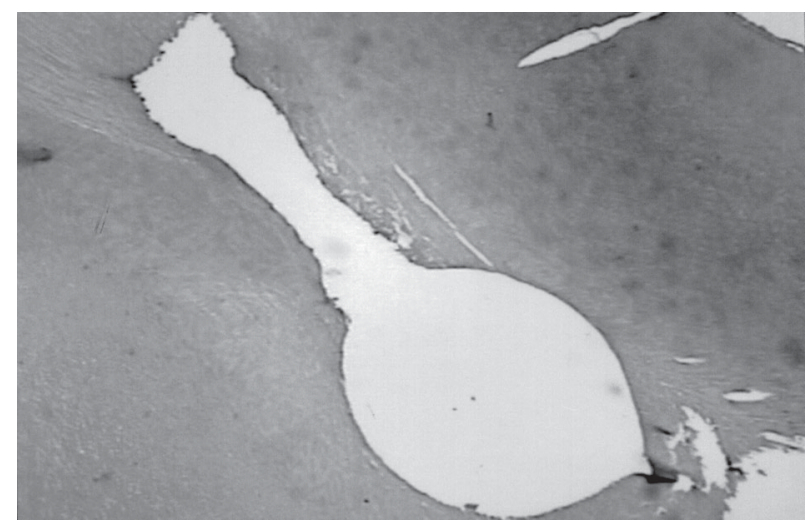

Figure 4. Apical third with a round preparation after instrumentation with ProFile taper .04 nickel-titanium files and $5.0 \%$ sodium hypochlorite irrigation showing areas where the instrument did not touch (hematoxylin and eosin; original magnification, 40X). 
ical preparation (9). It must also be noted that in the present study the ProFile taper .04 was used because the higher cleaning percentage $(97.14 \%)$ was found in roots instrumented by this type of file (8).

It is believed that thorough debridement before sealing is a key to long-term successful endodontic therapy. This study demonstrates the efficacy of $\mathrm{NaOCl}$ for the physical removal of superficial debris from root canal surfaces and the chemical removal of organic pulp debris from un-instrumented areas of a flattened root canal. More than $89 \%$ of pulp debris was removed with all concentrations of $\mathrm{NaOCl}$ tested in the present study. However, this study also confirms that $5 \% \mathrm{NaOCl}$ was more effective for removal of debris than $0.5 \%$ $\mathrm{NaOCl}$, when tested under the above mentioned conditions. The $1 \% \mathrm{NaOCl}$ showed an intermediate value of debris removal with no statistical differences $(\mathrm{p}>0.01)$ compared to the other two concentrations. Distilled water was shown to be ineffective for removal of pulp debris when compared to $\mathrm{NaOCl}$.

Variuos factors interfere with pulp tissue dissolution: a) quantity of solution related to organic tissue; b) contact surface; c) action time; d) solution volume; e) mechanical agitation; f) solution temperature; g) solution concentration (10-14). Thus, the higher these values the better the dissolution capacity of $\mathrm{NaOCl}$ on organic debris.

The chemical removal of organic tissue by $\mathrm{NaOCl}$ occurs by the release of hypochlorous acid, which reacts with insoluble proteins to form soluble polypeptides, amino acids, and other by-products (15). With regular exchange of the irrigant, the efficacy of the chemical reaction may be enhanced. Frequent exchange of the irrigant and the use of large quantities of irrigant should not only remove superficial debris but also replenish the chemical activity of $\mathrm{NaOCl}$ which is depleted by reacting with organic tissue (16). In this study, a total of $22 \mathrm{ml}$ of irrigant was used in the root canals for only $210 \mathrm{~s}$, which could explain the better results for more concentrated $\mathrm{NaOCl}(5 \%)$. If $\mathrm{NaOCl}$ is replenished often and allowed to remain in the root canal system for a longer period of time, more complete chemical removal of organic debris would be expected to take place (16).

Therefore, the endodontist must have these concepts in mind because the Profile .04 system is rapid, diminishing the time between instruments and consequently the period that the irrigating solution is in the root canal, even when using more concentrated solutions.

\section{RESUMO}

O presente estudo avaliou a capacidade de limpeza promovida pela técnica de instrumentação rotatória, com limas de níqueltitânio Profile .04, associado à soluções de hipoclorito de sódio $(\mathrm{NaOCl})$, em diferentes concentrações, quando utilizados em canais com achatamento mésio-distal. Vinte dentes incisivos centrais inferiores humanos, unirradiculares, foram selecionados e divididos aleatoriamente em 4 grupos: Grupo I: $\mathrm{NaOCl}$ a $0,5 \%$; Grupo II: $\mathrm{NaOCl}$ a 1\%; Grupo III: $\mathrm{NaOCl}$ a 5\%; Grupo IV: água destilada e deionizada. Após o preparo biomecânico, os dentes foram submetidos ao processamento histológico e análise morfométrica. A análise morfométrica mostrou que o $\mathrm{NaOCl}$ a $5 \%$ era estatisticamente mais eficiente na limpeza do canal radicular que o $\mathrm{NaOCl}$ a $0.5 \%$ e a água destilada, que apresentaram os mais baixos níveis de limpeza dos canais radiculares $(\mathrm{p}<0,01)$

\section{REFERENCES}

1. Schilder H. Cleaning and shaping of the root canal. Dent Clin N Am 1974;18:269-296.

2. Fariniuk LF, Baratto-Filho F, Guerisoli DMZ, Barbizam JVB, Pécora JD, Sousa-Neto MD. Modeling capacity of ENDOflash files in simulated root canals. Braz Dent J 2001;12:39-42.

3. Siqueira-Jr JF, Araújo MCP, Garcia PF, Fraga RC, Sabóia-Dantas CJ. Histological evaluation of effectiveness of five instrumentation techniques for cleaning the apical third of root canals. J Endodon 1997;23:499-502.

4. Barbizam JVB, Fariniuk LF, Marchesan MA, Pécora JD, SousaNeto MD. Effectiveness of manual and rotary instrumentation techniques for cleaning flattened root canals. J Endodon 2002;28:365-366.

5. Baumgartner JC, Mader CL. A scanning electron microscopic evaluation of four root canal irrigation regimes. J Endodon 1987;4:147-157.

6. Hand RE, Smith ML, Harrison JW. Analysis of the effect of dilution on the necrotic tissue dissolution property of sodium hypochlorite. J Endodon 1978;4:60-64.

7. Gambarini G. Shaping and cleaning the root canal system: a scanning electron microscopic evalution of a new instrumentation and irrigation technique. J Endodon 1999;25:800-803.

8. Fariniuk LF, Baratto-Filho F, Cruz-Filho AM, Sousa-Neto MD. Histologic analysis of the cleaning capacity of mechanic endodontic instruments activated by the ENDOflash system. J Endodon 2003;29:651-653.

9. Hulsmann M, Rummelin C, Schafers F. Root canal cleanliness after preparation with different endodontic handpieces and hand instruments: A comparative SEM investigation. J Endodon 1997;23:310-316

10. Spanó JCE, Barbin EL, Santos TC, Guimarães JF, Pécora JD. Solvent action of sodium hypochlorite on bovine pulp and physico-chemical properties of resulting liquid. Braz Dent $\mathbf{J}$ 2001;12:154-157.

11. Hand RE, Smith ML, Harrison JW. Analysis of the effect of dilution on the necrotic tissue dissolution property of sodium hypochlorite. J Endodon 1978;4:60-64. 
12. Thé SD, Maltha JC, Plasschaert AJM. Reaction of guinea pig subcutaneous connective tissues following exposure to sodium hypochlorite. Oral Surg Oral Med Oral Pathol 1980;49:460-466.

13. Cunninghan WT, Balekjian AY. Effect of temperature on collagen-dissolving ability of sodium hypochlorite endodontic irrigant. Oral Surg Oral Med Oral Pathol 1980;49:175-177.

14. Gordon TM, Damato D, Christner P. Solvent effect of various dilutions of sodium hypochlorite on vital and necrotic tissue. J Endodon 1981;7:466-469.

15. Baumgartner JC, Ibay AC. The chemical reactions of irrigants used for root canal debridement. J Endodon 1987;13:47-51.

16. Baumgartner JC, Cuenin PR. Efficacy of several concentrations of sodium hypochlorite for root canal irrigation. J Endodon 1992;18:605-612.

Accepted July 23, 2003 